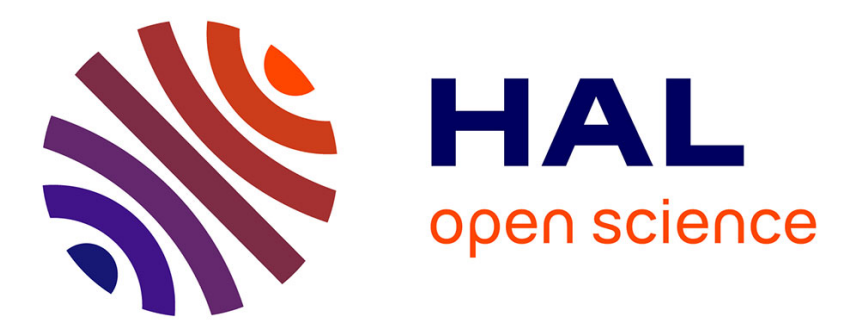

\title{
Wetland seasonal dynamics and interannual variability over northern high latitudes, derived from microwave satellite data
}

\author{
Arnaud Mialon, A. Royer, Michel Fily
}

\section{- To cite this version:}

Arnaud Mialon, A. Royer, Michel Fily. Wetland seasonal dynamics and interannual variability over northern high latitudes, derived from microwave satellite data. Journal of Geophysical Research: Atmospheres, 2005, 110 (D17102), 1 à 10 p. 10.1029/2004JD005697 . insu-00374874

\section{HAL Id: insu-00374874 \\ https://hal-insu.archives-ouvertes.fr/insu-00374874}

Submitted on 19 Feb 2021

HAL is a multi-disciplinary open access archive for the deposit and dissemination of scientific research documents, whether they are published or not. The documents may come from teaching and research institutions in France or abroad, or from public or private research centers.
L'archive ouverte pluridisciplinaire HAL, est destinée au dépôt et à la diffusion de documents scientifiques de niveau recherche, publiés ou non, émanant des établissements d'enseignement et de recherche français ou étrangers, des laboratoires publics ou privés. 


\title{
Wetland seasonal dynamics and interannual variability over northern high latitudes, derived from microwave satellite data
}

\author{
A. Mialon \\ Laboratoire de Glaciologie et Géophysique de l'Environnement, CNRS/UJF, Grenoble, France \\ Centre d'Applications et de Recherches en Télédétection, Université de Sherbrooke, Sherbrooke, Quebec, Canada
}

\begin{abstract}
A. Royer
Centre d'Applications et de Recherches en Télédétection, Université de Sherbrooke, Sherbrooke, Quebec, Canada
\end{abstract}

M. Fily

Laboratoire de Glaciologie et Géophysique de l'Environnement, CNRS/UJF, Grenoble, France

Received 13 December 2004; revised 6 May 2005; accepted 9 June 2005; published 3 September 2005.

[1] A new accurate determination of the spatial and temporal variations of northern wetland area extent, during the snow-free period, is retrieved from the 19- and 37-GHz passive microwave Special Sensor Microwave/Imager (SSM/I) brightness temperature database. The total fraction of water surface (FWS) area, corresponding to small lakes or reservoirs (area $<25 \times 25 \mathrm{~km}^{2}$ ), inundated surfaces and natural wetland areas, computed on a weekly basis and averaged over the 1988-2001 period, gives a maximum summer extent of $10.10 \pm 0.21 \times 10^{5} \mathrm{~km}^{2}$ for Canada and Alaska and $12.7 \pm 0.35 \times 10^{5} \mathrm{~km}^{2}$ for Eurasia, above $50^{\circ} \mathrm{N}$. The mean seasonal dynamics of wetland and inundated surfaces shows a maximum area extent during the months of July-August-September over North America $\left(48^{\circ} \mathrm{N}-68^{\circ} \mathrm{N}\right)$ and between June and September over northern Eurasia. The interannual variations of the yearly total FWS area since 1988 show a slight increase $(8 \% \pm 3 \%)$ in Canada-Alaska, mainly due to a decrease in the snow cover extent. The FWS interannual variability in the $\mathrm{Ob}$ River basin, which is well explained by the water discharge variations, shows an increase of $8.5 \% \pm 1.5 \%$ between 1988 and 2001. The microwave-derived FWS estimate and its dynamics present an interesting potential for studying the climate-driven variability of wetlands and inundated areas.

Citation: Mialon, A., A. Royer, and M. Fily (2005), Wetland seasonal dynamics and interannual variability over northern high latitudes, derived from microwave satellite data, J. Geophys. Res., 110, D17102, doi:10.1029/2004JD005697.

\section{Introduction}

[2] The extent of northern inundated surfaces and wetlands, and their dynamics at regional or continental scale are very difficult to determine because of the lack of data and the heterogeneity of these types of surfaces at the model scale. Existing global data sets are generally non-dynamic inventories [Cogley, 2003; Fernandes et al., 2001; Matthews and Fung, 1987] and are defined mainly by ecology and soil classification. However, inundated surfaces are an important climate factor because of the exchange of greenhouse gases with the atmosphere. Most northern wetlands and shallow lakes $(<2 \mathrm{~m}$ deep) are both net sinks for atmospheric carbon dioxide $\left(\mathrm{CO}_{2}\right)$ and sources for methane, and deeper lakes are in general net sources of $\mathrm{CO}_{2}$ [Roulet et al., 1994; Griffis et $a l ., 2000]$. Characterization of both the climate-driven variations of the carbon budget and the climate feedback effect of

Copyright 2005 by the American Geophysical Union. 0148-0227/05/2004JD005697 wetlands over northern latitudes requires the accurate determination of [Poutou et al., 2004]: (1) the summer seasonal and interannual variations of wetland area extent [Winter and Rosenberry, 1998; DeNoblet-Ducoudré et al., 2002], (2) and the snow- and frost-free period duration, when wetlands are photochemically active [Roulet et al., 1994; Walter et al., 2001; Krinner, 2003]. Climate models try to take into account these wetlands [Krinner, 2003], as their role in climate is important. Hence more data are needed to provide the seasonal dynamics of inundated surfaces.

[3] Remote sensing data appear as the only alternative to the lack of in situ measurements over high latitudes. Passive microwave systems are particularly adequate as they have shown their ability to distinguish water areas from other surfaces [Basist et al., 1998]. Prigent et al. [2001] also used remote sensing data from several sensors and a neural network approach, for monitoring wetland dynamics at the global scale of 1 year (July 1992 through June 1993).

[4] We present here, for the first time, a detailed analysis of the wetland seasonal and interannual dynamics on a 


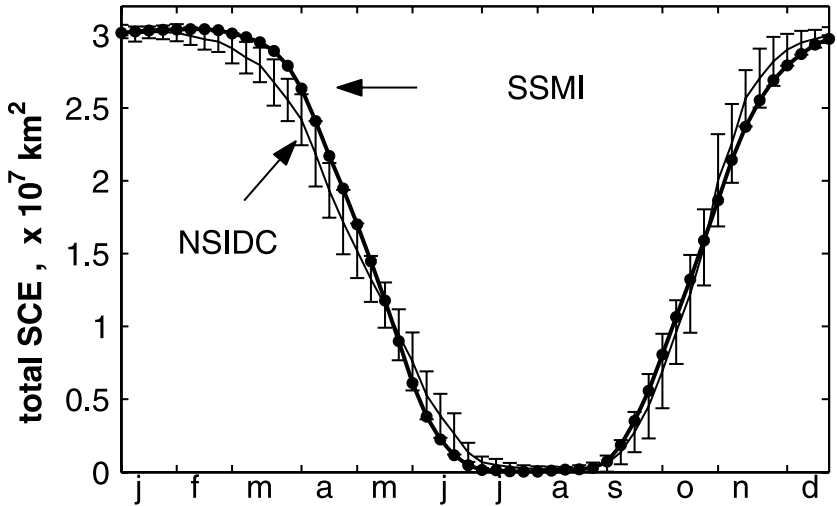

Figure 1. Seasonal variation of the total snow cover extent (total SCE) over Canada-Alaska and northern Eurasia derived from the thresholded microwave brightness temperature approach (SSMI: dot and bold line) and from the Northern Hemisphere EASE-Grid Weekly Snow Cover and Sea Ice Extent NSIDC product (shaded line, with error bars) for the 1988-2001 period. Error bar data correspond to 1 standard deviation.

weekly basis over Canada-Alaska and northern Eurasia using the 1988-2001 DMSP SSM/I Pathfinder Daily EASE-Grid Brightness Temperatures product. The interannual variation of the snow cover extent is obtained from the same database and discussed for the same areas.

\section{Data Processing}

2.1. Extraction of the Fraction of Water Surface (FWS)

[5] This study is based on a new simple method developed to retrieve the microwave land-surface emissivity from the DMSP SSM/I Pathfinder Daily EASE-Grid Brightness
Temperatures product distributed by the National Snow and Ice Data Center (NSIDC) in Boulder, Colorado [Armstrong et al., 2005]. Separation of surface temperature and emissivity from the measured brightness temperature at 19.35 and $37 \mathrm{GHz}$ is achieved after atmospheric correction by using an observed significant empirical relationship between surface emissivities at horizontal and vertical polarizations over snow- and ice-free land surfaces. The method is described in detail by Fily et al. [2003]. Microwave emissivities strongly decrease when the fraction of water increases in the observed pixel, because the water emissivity is significantly smaller $(<0.5$ depending on the frequency) than for most of the land cover types [Prigent et al., 1998]. Microwave emissivity also decreases when the soil moisture in the first few centimeters increases [Owe et al., 1999], but to a lesser extent. Thus, from the retrieved emissivities, one can estimate, for each pixel of the twice-daily SSM/I images, a fraction of water surface extent (FWS) within the pixel at the time of image acquisition. FWS is simply defined from

$$
\varepsilon_{p}=\varepsilon_{\text {water }} \times F W S+\varepsilon_{d r y} \times(1-F W S),
$$

where $\varepsilon_{p}$ is the measured emissivity at polarization $p$ (vertical or horizontal), $\varepsilon_{d r y}$ is the emissivity of a dry surface, and $\varepsilon_{\text {water }}$ is the water emissivity.

[6] FWS corresponds to a combination of different surface contributions including small lakes or reservoirs (where small means smaller than one EASE-Grid SSM/I pixel), shallow open water, saturated wet surfaces over poorly drained soils, intermittent inundated (flooded) surfaces at the time of data acquisition, swamps, ponds, marshes, fens, bogs or peats. FWS is also somewhat related to soil moisture.
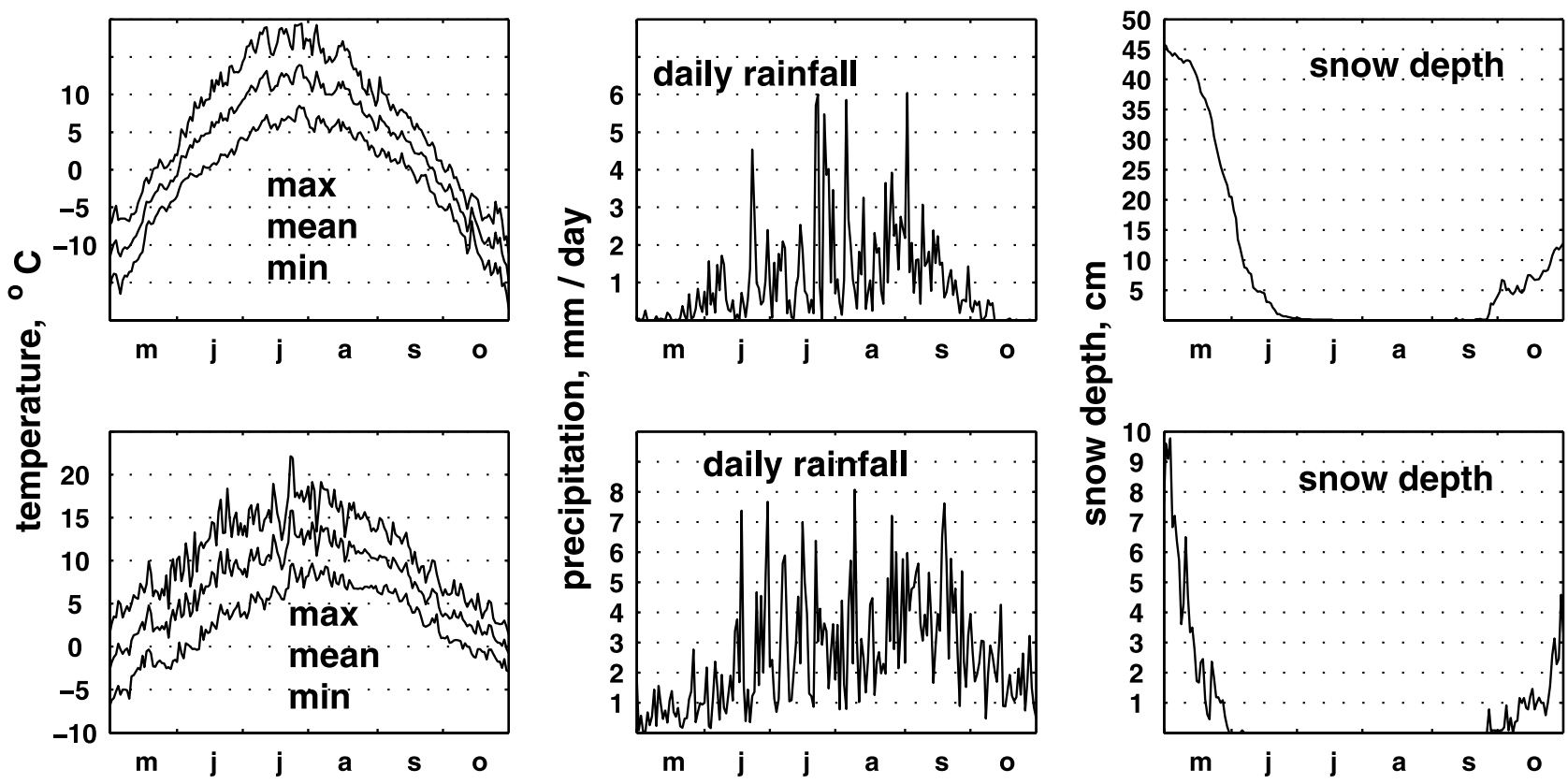

Figure 2. Mean climatology (from May to October) for the averaged 1988-2001 period (from left to right: air temperature, daily mean, maximum and minimum; daily rain rate; and daily snow depth) for two stations: Baker Lake $\left(64^{\circ} 18^{\prime} \mathrm{N}-96^{\circ} 5^{\prime} \mathrm{W}\right)$ (top) and Kuujjurapik $\left(55^{\circ} 17^{\prime} \mathrm{N}-77^{\circ} 45^{\prime} \mathrm{W}\right)$ (bottom). Mean values give 104 and 168 days without snow at Baker Lake and Kuujjurapik, respectively. 
a)

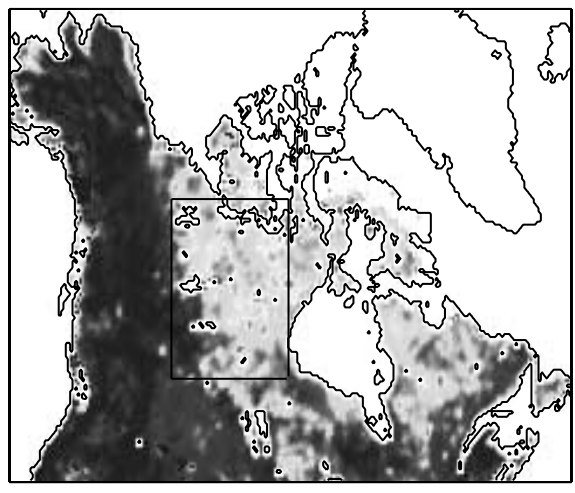

FWS

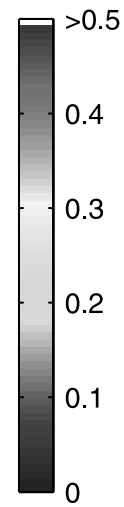

b) Great Slave Lake

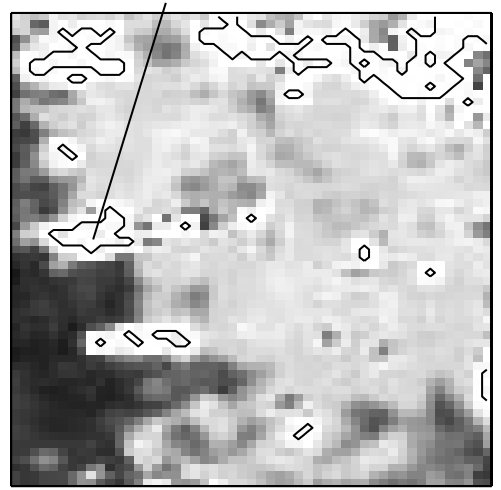

c)

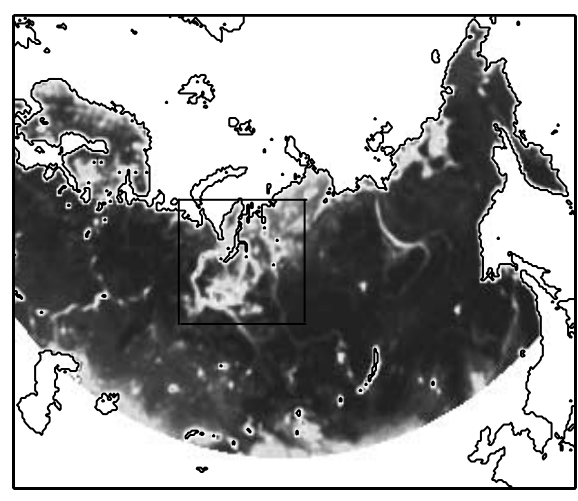

FWS

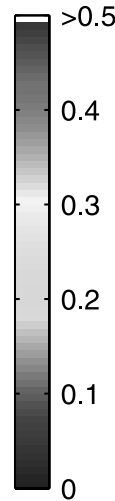

d)

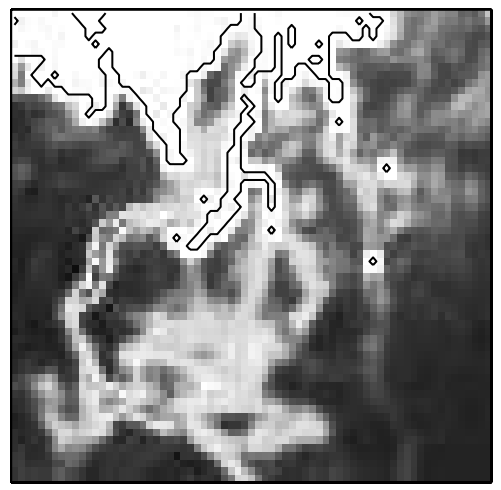

Figure 3. Fraction of water surface distribution giving the mean wetland and waterbody extent (a) over Canada-Alaska and (b) over the MacKenzie basin, for week 37, and (c) over northern Eurasia and (d) over the $\mathrm{Ob}$ basin for week 27, averaged over the 1988-2001 period, at $37 \mathrm{GHz}$, vertical polarization and AM overpasses. Coastal zones, large lakes and Northern Islands are masked (white areas). See color version of this figure at back of this issue.

[7] The same $\varepsilon_{\text {water }}$ as Fily et al. [2003] (i.e., 0.664 at $37 \mathrm{GHz}$ and 0.588 at $19 \mathrm{GHz}$, both at vertical polarization) are used as they were precisely computed from Fresnel equations. On the other hand, the satellite-derived FWS are very sensitive to the emissivity used for the dry surface $\left(\varepsilon_{d r y}\right)$. For low FWS values of about $5 \%$, a slight variation of $1 \%$ of $\varepsilon_{d r y}$ can induce a large relative variation of about $40 \%$ of FWS results (i.e., an absolute FWS variation of $2 \%$ ). For high FWS (higher than 20\%), the same variation of $\varepsilon_{d r y}$ induces a smaller relative FWS variation (about 7\%, i.e., an absolute FWS variation of $1.5 \%$ ). Indeed, a more detailed analysis than that of Fily et al. [2003] was carried out using the Fernandes et al. [2001] waterbody areas independent data set over the driest parts of Canada. The derived values are $\varepsilon_{d r y}=0.965$ at $37 \mathrm{GHz}$ and $\varepsilon_{d r y}=0.980$ at $19 \mathrm{GHz}$, both at vertical polarization. The sensitivity of low FWS to small $\varepsilon_{d r y}$ variations led us to select high FWS areas ( $>10 \%$ over Canada-Alaska, the Ob basin over northern Eurasia) for interannual variation studies (section 3.3.2).

[8] The lack of dependence of FWS on the cloud opacity was checked with meteorological data over a few sites. The inversion was processed only when the pixels were considered as snow and ice free, as the method is not valid otherwise. The method for selecting valid pixels is described below.

\subsection{Selection of Days Without Snow}

[9] Grody and Basist [1996] used the difference between the 19- and $37-\mathrm{GHz}$ vertically polarized brightness temperatures $(\mathrm{Tb} 37 \mathrm{~V}-\mathrm{Tb} 19 \mathrm{~V})$ with other criteria to detect the presence of snow. We used a similar parameter that we called $\Delta \mathrm{Tb}$, which is the normalized difference: $[\Delta T b=$ $(37 \mathrm{~V}-19 \mathrm{~V}) / 19 \mathrm{~V}]$. To avoid wet snow (thawing snow) effect during spring, only morning overpass brightness temperatures are kept. An adaptative threshold is applied to the seasonal variation of $\Delta \mathrm{Tb}$ for the selection of the snow- and ice-contaminated pixels. The threshold is determined from the July-August $\Delta \mathrm{Tb}$ values (mean value minus two standard deviations) independently for each pixel and each year of the database. This takes into account the land-cover type variation, as well as the possible drift or changes between measurement conditions (mainly variations in the time of the satellite overpasses [Armstrong et al., 2005]. A median filter with a 23-day window is applied to the $\Delta \mathrm{Tb}$ series before thresholding in order to avoid spurious data. 

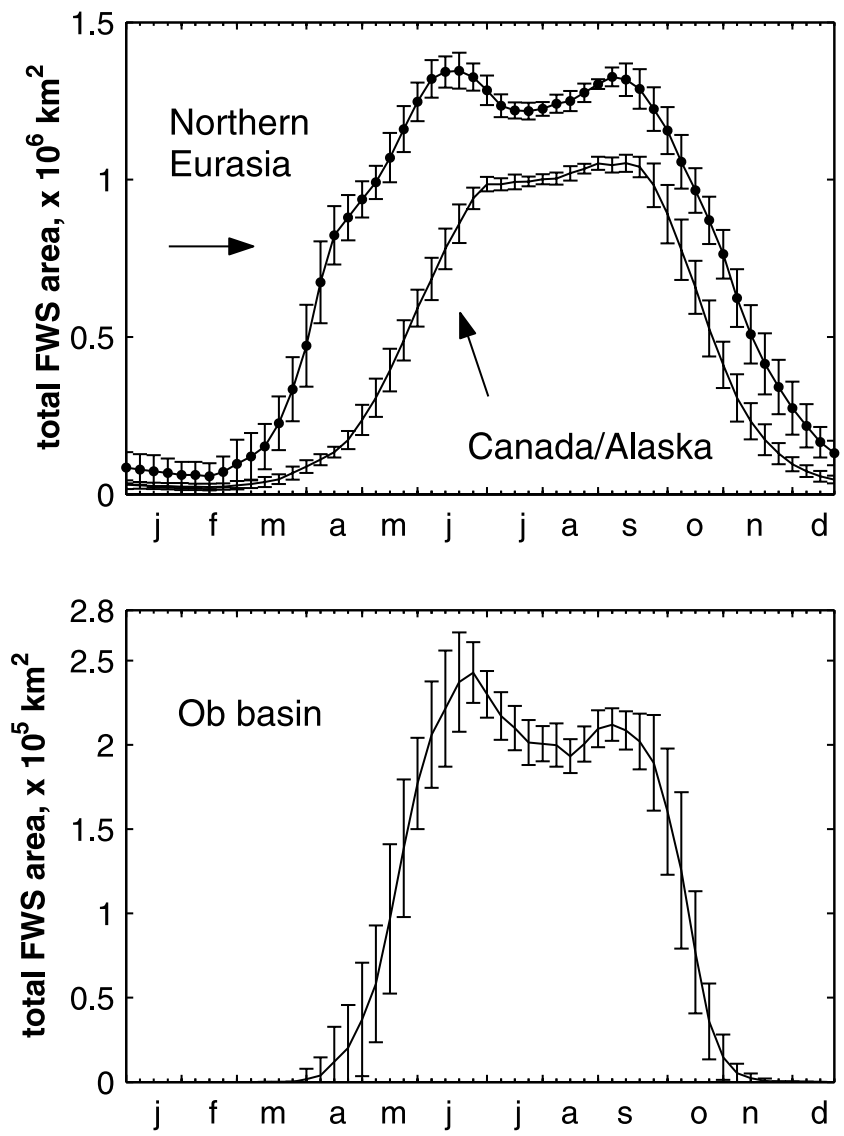

Figure 4. Mean seasonal variation of the wetland and waterbody extent (total fraction of water surface area) (top) over Canada-Alaska and over northern Eurasia and (bottom) over the $\mathrm{Ob}$ basin, retrieved from the morning (AM) satellite overpass $37 \mathrm{GHz}$ data. The weekly values, averaged over the 1988-2001 period, are shown with \pm 1 standard deviation.

[10] This approach was compared to an independent data set derived from the NSIDC Northern Hemisphere EASEGrid Weekly Snow Cover and Sea Ice Extent Version 2 product [Armstrong and Brodzik, 2002] (Figure 1), based mainly on the manual interpretation of the Advanced Very High Resolution Radiometer (AVHRR) on board the NOAA satellites. The comparison between SSM/I- and AVHRR-derived snow cover extent for Canada-Alaska and northern Eurasia averaged over the same 1988-2001 period shows very similar patterns $\left(r^{2}=0.99\right)$, with a slight overestimation (underestimation) for the beginning of spring (fall) periods of $+(-) 6 \%$ maximum (Figure 1 ) for the microwave-derived series relative to the AVHRRderived data. The slight underestimation found at the end of spring (weeks 21-27) is in accordance with Wang et al. [2005] new results based on Landsat TM, SSM/I and in situ observations.

[11] As the FWS are initially computed on a daily basis, we prefer to use our daily microwave derived snow cover mask instead of the weekly NSIDC product. Moreover, the $\mathrm{SSM} / \mathrm{I}$ EASE Grid spatial resolution is smaller than the initial NSIDC snow cover resolution $(190 \mathrm{~km})$. A more complete comparison of our microwave derived snow cover with the NSIDC is presented elsewhere [Mialon et al., 2005].

[12] We also checked the accuracy of our approach by comparing the snow cover cycle with in-situ meteorological data. Figure 2 shows the mean 1988-2001 climatology (temperature, rain rate and snow depth) for two reference stations having a complete time series of data, Baker Lake and Kuujjurapik, respectively, in the northwest and eastern Canada. The snow-free duration derived from SSM/I data is very similar (difference $<1 \%$ ) to the period when the snow depth is $<3 \mathrm{~cm}$ in situ, as thin layers (about $3 \mathrm{~cm}$ ) of dry snow cannot be seen at 19 and $37 \mathrm{GHz}$ [Grody and Basist, 1996; Armstrong and Brodzik, 2001].

\section{Results and Discussion}

[13] FWS values are averaged on a weekly basis from 1988 to 2001 for both frequencies (19 and $37 \mathrm{GHz}$ ), separately for morning (AM) and afternoon (PM) satellite overpasses.

\subsection{Wetland Extent}

[14] We present, in Figure 3, the spatial coverage of the 1988-2001 mean fraction of water surface (FWS) derived from SSM/I emissivities for our study areas at $37 \mathrm{GHz}$, vertical polarization and for AM overpasses: Canada-Alaska (between $58^{\circ} \mathrm{W}$ and $170^{\circ} \mathrm{W}$ and between $39^{\circ} \mathrm{N}$ and $75^{\circ} \mathrm{N}$ ) (week 37), northern Eurasia (between $50^{\circ} \mathrm{N}$ and $75^{\circ} \mathrm{N}$ and $10^{\circ} \mathrm{E}$ and $172^{\circ} \mathrm{E}$ ) (week 27) and two sub-areas over the MacKenzie basin in Northwest Canada $\left(54^{\circ} \mathrm{N}-70^{\circ} \mathrm{N}\right.$; $94^{\circ} \mathrm{W}-125^{\circ} \mathrm{W}$ ) and the $\mathrm{Ob}$ basin in Northwest Siberia $\left(58^{\circ} \mathrm{N}-74^{\circ} \mathrm{N} ; 50^{\circ} \mathrm{E}-99^{\circ} \mathrm{E}\right)$. Note that we applied a mask along the coast to avoid boundary effects (mixed pixels), for large lakes (area $>25 \times 25 \mathrm{~km}^{2}$ ), for some mountainous glaciers and for the Northeast Arctic Islands (permanent ice cap). The spatial distribution of FWS was validated with the detailed $1 \mathrm{~km}^{2}$ resolution Canadian waterbody map from Fernandes et al. [2001]. The difference is less than 3\% when the total FWS area over Canada is considered.

[15] For mixed pixels with snow-free-land and icecovered-lakes (during spring), no water $(\mathrm{FWS}=0)$ is found because ice/snow emissivity is larger than water emissivity. For mixed pixels with snow-covered land and ice-free lakes we may underestimate FWS if the pixel is considered as snow covered. This could happen in autumn if the snow cover is deep enough $(>3 \mathrm{~cm})$. In this case, we would overestimate the snow cover extent compared to the NSIDC (visible sensors, sensitive to open water). As this is not the case (Figure 1), we suppose that this effect is not important for our FWS results.

[16] On the maps (Figure 3), one can recognize some significant features corresponding to the main rivers and basins such as the $\mathrm{Ob}$ and Lena in Siberia and the MacKenzie in Northwest Canada. Canada-Alaska are covered by plenty of reservoirs, lakes and a lot of small rivers connecting to open waters areas. Two regions in the northern part of the province of Quebec and in the Nunavut are also characterized by very dense waterbodies.

[17] The mean summer wetland and inundated surface area estimated by this new method is $10.10 \pm 0.21 \times$ $10^{5} \mathrm{~km}^{2}$ for Canada and Alaska and 12.70 $\pm 0.35 \times$ $10^{5} \mathrm{~km}^{2}$ for Eurasia above $50^{\circ} \mathrm{N}$. The estimated accuracy 

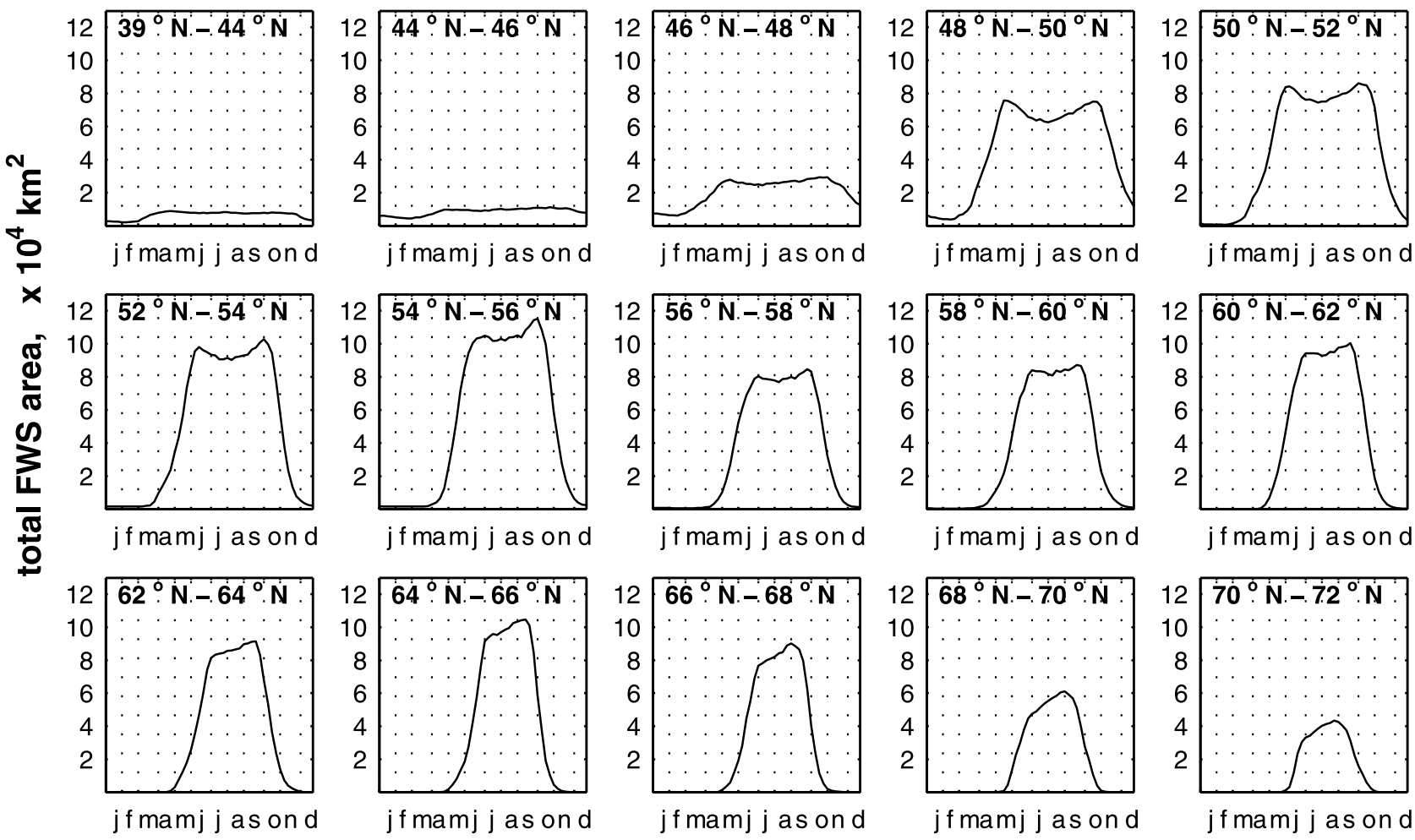

Figure 5. Latitudinal variation (every $2^{\circ}$, except for southern latitudes, $39^{\circ} \mathrm{N}-44^{\circ} \mathrm{N}$, where FWS are small) of the seasonal dynamics of the wetland and waterbody extent (total fraction of water surface area $\times 10^{4} \mathrm{~km}^{2}$ ) over Canada-Alaska for the 1988-2001 period.

corresponds to one standard deviation of the interannual variation of the FWS parameter $(2-3 \%$ of the mean value) showing the relative stability of this parameter.

[18] The estimated Canada-Alaska area is close to the one proposed by Cogley [2003] (wetlands + small lake areas: $\left.10.7810^{5} \mathrm{~km}^{2}\right)$, but is larger than for the global data sets from Matthews and Fung [1987] $\left(8.5810^{5} \mathrm{~km}^{2}\right)$ or Latifovic et al. [2002] (wetlands + waterbody areas: $8.3010^{5} \mathrm{~km}^{2}$ ) for the same region. This comes mainly from the fact that they do not consider the same definition for wetlands. For example, Matthews and Fung [1987] consider only swamps and bogs over both non forested and forested area. Moreover, our estimate compares well with the Prigent et al. [2001] wetland area $\left(11.0 \times 10^{5} \mathrm{~km}^{2}\right)$, also derived from satellite data but using another approach based on a neural network. There is a slight observed difference of $8.8 \%$ but, if only the area with FWS $>5 \%$ is kept, we find the same total wetland area value as Prigent et al. [2001] for the same year of analysis (1992). Large areas where FWS is small, mainly in the western part of Canada and Alaska (Figure 3), are not considered by Prigent et al. [2001]. In these areas, our results are close to Fernandes et al. [2001] and Latifovic et al. [2002].

[19] For the $\mathrm{Ob}$ river basin, the mean May-June water area extent derived from Prigent et al. [2001] $(2.65 \times$ $\left.10^{5} \mathrm{~km}^{2}\right)$ falls between our mean value $\left(2.2 \times 10^{5} \mathrm{~km}^{2}\right)$ and the observed maximum value for this year $(2.73 \times$ $10^{5} \mathrm{~km}^{2}$ ). For this area, the temporal sampling of the data is important as, during the rapid river discharge period, FWS varies significantly. For this basin, the wetland databases from Cogley [2003] and Matthews and Fung
[1987] give, respectively, an area of $3.8 \times 10^{5} \mathrm{~km}^{2}$ (wetland and lakes categories), and $5.2 \times 10^{5} \mathrm{~km}^{2}$ (wetland extent). The differences could be explained by the resolution of these databases $\left(1^{\circ}\right.$ by $1^{\circ}$, i.e., approximately 270 pixels instead of 4330 in our case).

[20] We assessed the difference between the mean summer FWS extent derived from 19- and 37-GHz emissivities and for AM and PM satellite overpass times. For both frequencies, the total FWS extent from AM overpass time data is very close ( $2 \%$ higher) to the one derived from the PM overpass time data. For Canada and Alaska, the results at $19 \mathrm{GHz}$ give a slightly larger wetland area extent $(+3.1 \%)$ than at $37 \mathrm{GHz}$. When only FWS $(19 \mathrm{GHz})$ values $>5 \%$ are considered, the total wetland area is very similar to the one at $37 \mathrm{GHz}$. In all cases, the seasonal variation is exactly the same.

\subsection{Seasonal Wetland Dynamics}

[21] Very few global observations of wetland dynamics are available over a full year or longer. Only Prigent et al. [2001] give monthly data for 1 year (from July 1992 to June 1993). Our objective here is to give, on a weekly basis, a mean seasonal wetland dynamics averaged over a long period (1988-2001). Figure 4 shows the typical mean wetland and inundated area (averaged 1988-2001 total fraction of water surface area) for Canada-Alaska and northern Eurasia. The error bars correspond to the standard deviation of the 13-year series and then represents the interannual variability for each week.

[22] The wetland dynamics in Canada-Alaska is characterized by a marked plateau during the months of July, 


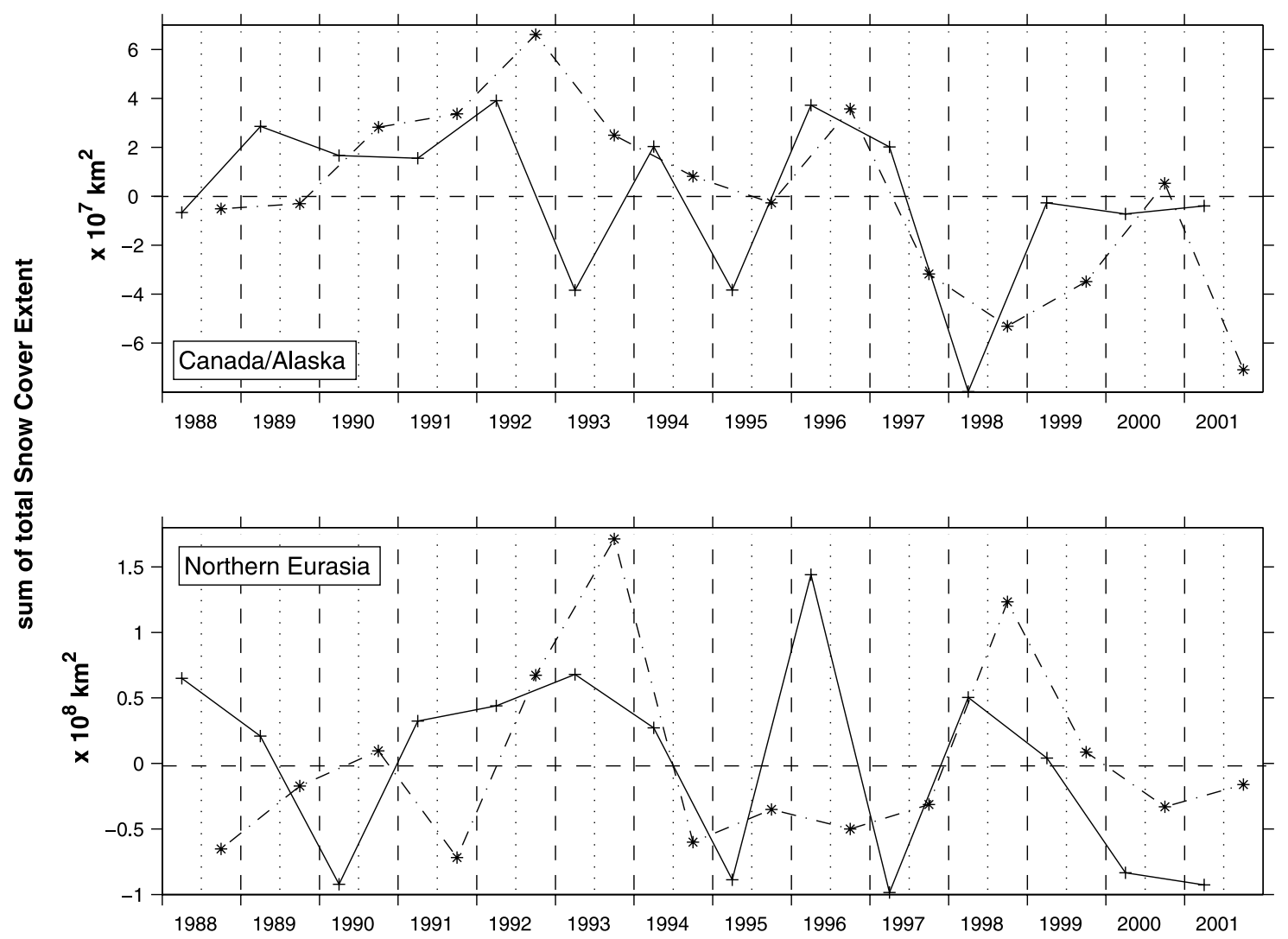

Figure 6. Variation of the anomalies (1988-2001 period), of the sum of total daily snow cover extent, (top) over Canada-Alaska, and (bottom) over northern Eurasia, derived from SSM/I satellite data. The solid lines (pluses) correspond to the first half of the year (sum of days of the year: DOY 32 to 217), covering the spring period; the dotted lines (asterisks) correspond to the second half of the year (DOY 218 to 365 of the year $i+$ DOY 1 to 31 of the year $i+1$ ), covering the fall period.

August and September, between a rapid increase (decrease) during the spring (fall) corresponding to the melting (onset) snow/freeze period. The interannual variability is very small during the summer $(2 \%)$ and larger during the intermediate seasons owing to the large variability of the melting and onset of the snow. The observed seasonal behavior of wetland extent (Figure 4) is somewhat different from the one already discussed by Prigent et al. [2001] showing a rapid decrease in wetland areas $(-32 \%)$ for the month of September 1992. The difference corresponds to the northern part of Canada and Alaska (latitude $>58^{\circ} \mathrm{N}$ and $>61^{\circ}-62^{\circ} \mathrm{N}$, respectively, for the east and west of Hudson's Bay), where we found large unfrozen and snow-free open waterbodies. Our results are in agreement with the AVHRR-NSIDC snow cover extent analysis (Figure 1) and also with meteorological data (Figure 2) which show that the mean temperature is still above $0^{\circ} \mathrm{C}$ with significant rain precipitation during September. The latitudinal analysis of wetland extent over Canada-Alaska (every $2^{\circ}$ of latitude, Figure 5) shows similar patterns for the seasonal variation, with a significant summer plateau including September up to $66^{\circ} \mathrm{N}$. The wetlands are rather homogeneously distributed between $48^{\circ} \mathrm{N}$ and $68^{\circ} \mathrm{N}$ in Canada but the length of the active period is clearly dependent on the latitude, from 26 weeks at $48^{\circ} \mathrm{N}-50^{\circ} \mathrm{N}$ to 11 weeks at $66^{\circ} \mathrm{N}-68^{\circ} \mathrm{N}$.

[23] For northern Eurasia, wetlands are mainly found in Fennoscandia, along the coast and in the $\mathrm{Ob}$ basin (FWS $>$
$10 \%$ for $23 \%$ of the total area). We selected the $\mathrm{Ob}$ basin to illustrate the FWS seasonal dynamics (Figure 4, bottom). The $\mathrm{Ob}$ basin is one of the largest arctic watersheds and is largely located within the west Siberian plain characterized by large flooded areas. We observe in this region a different seasonal dynamics behavior: Two peaks are clearly noticeable separated by the drier summer season (Figure 4).

[24] For the $\mathrm{Ob}$ basin, the active period is 14 weeks (between around $62^{\circ} \mathrm{N}$ and $66^{\circ} \mathrm{N}$ ), compared to the 13 -week period for Canada-Alaska at the same latitudes. The first maximum in May-June results from the progressive latitudinal (south to north) snowmelting, yielding to a maximum flow and water surface extent when the flood wave begins to break the ice cover [see Kouraev et al., 2004]. Moreover, for this basin, there is an important interannual variability (error bars larger than for Canada-Alaska) even during summer (Figure 4) (see section 3.3).

\subsection{Interannual Variation}

[25] As shown for seasonal wetland variations, wetland dynamics are strongly linked to the snow cover. Wetland interannual variability is thus analyzed first through the snow cover extent variations, then the results on the fraction of water surface variations are presented for the summer only (snow-free wetland variation) and for the whole year (snow and wetland variation). 


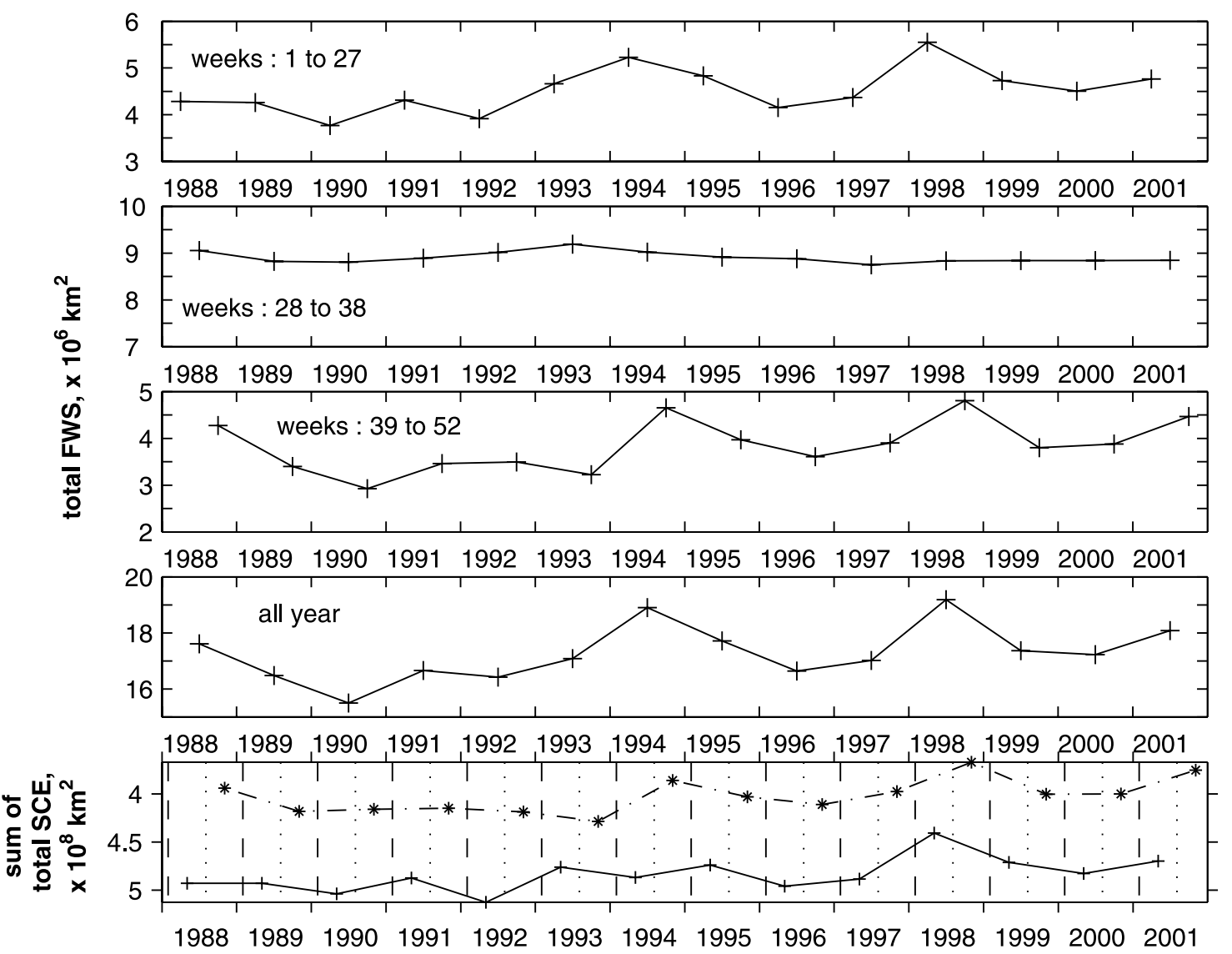

Figure 7. Variation of the sum of weekly computed FWS, for Canada-Alaska, over the 1988 to 2001 period. Top four plots, from top to bottom, are as follows: weeks 1 to 27 (covering the spring); weeks 28 to 38 (summer); weeks 39 to 52 (covering the fall); and weeks 1 to 52 (the whole year). (bottom) Sum of daily total snow cover extent (SCE) for the end of winter/spring (pluses) and fall/beginning of winter (asterisks) periods, calculated over the northern part of Canada $\left(>52^{\circ} \mathrm{N}\right)$ except Alaska and Rocky Mountains. Note that the scale is reversed to make easier the comparison between the total FWS area signal and the total snow cover extent signal.

\subsubsection{Interannual Snow Cover Extent Variation}

[26] In Figure 6, the sum of daily total snow cover extent (SCE) variations are given for Canada-Alaska (top) and northern Eurasia (bottom), during the 1988-2001 period. These results are derived on a pixel by pixel basis from our adaptative threshold method used for selecting the beginning and the end of the snow cover period. We distinguish the variations from the first half of the year (covering the spring) from the second half of the year (covering the fall). Several negative spring anomalies appear in 1993, 1995 and 1998 for Canada-Alaska, and in 1990, 1995 and 1997 for northern Eurasia, corresponding to snow seasons ending sooner. Positive fall anomalies appear in 1992 and 1996 for CanadaAlaska, and in 1993 and 1998 for northern Eurasia, corresponding to snow beginning earlier. A strong spring anomaly (longer winter) is also observed in 1996 over northern Eurasia. All these observed variations (Figure 6) are in accordance with the Brown [2000] analysis using ground-based data (considering the same period before 1997), and with the Northern Hemisphere EASE-Grid Weekly Snow Cover and Sea Ice Extent NSIDC product for the same period and areas studied. Moreover, a slight linear decreasing trend of $4 \%( \pm 1 \%$, with a statistical confidence Student test of $95 \%$ ) is observed for the total winter snow cover extent (not shown) for the 1988-2001 period in Canada-Alaska, also confirmed by the NSIDC database.

\subsubsection{Interannual Wetland Extent Variation}

[27] Figures 7 and 8 show the interannual variations of the sum of weekly wetland and inundated surfaces for four different periods (spring, summer, fall and total year). The sum of total fraction of water surface (FWS) area over several weeks for each period characterizes a time integrated parameter for a given period, similar to a total water supply. On these figures, we also report the total snow cover extent for the areas concerned (at the bottom). We kept the distinction between fall/beginning of winter and end of winter/spring for the snow cover dynamics as Brown [2000] outlines a different behavior for these periods in the interannual snow cover extent variability.

[28] For Canada-Alaska, we kept only areas with high FWS values $(>10 \%$, Figure 3$)$ corresponding to the northern part of Canada $\left(>52^{\circ} \mathrm{N}\right)$ without Alaska and the Rocky Mountains. Figure 7 shows almost no significant interannual change during the summer (maximum FWS deviation of $5 \%$ ), as already noticed on Figure 4. A clear increase in the integrated wetlands surface over the 1988-2001 period is observed during spring $(17 \% \pm 5 \%$, with a statistical confi- 


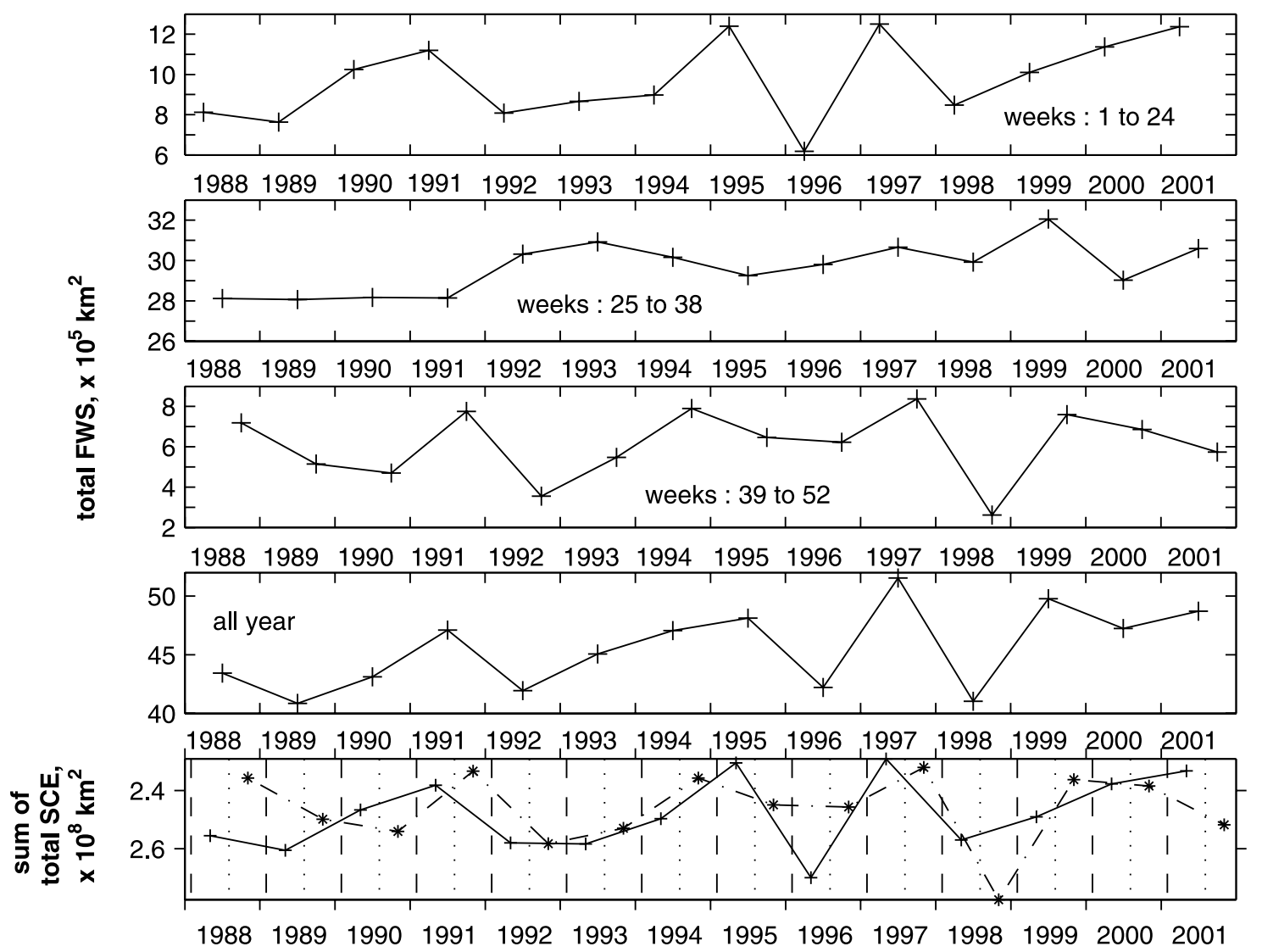

Figure 8. Same as Figure 7 but for the $\mathrm{Ob}$ River basin.

dence Student test of $95 \%)$ and fall $(20 \% \pm 5 \%$, with a statistical confidence of $95 \%$ ). These trends can be related to the decrease of the sum of total SCE over the same period, respectively, $-6.5 \%( \pm 1.5 \%$, with a statistical confidence Student test of $97.5 \%)$ and $-7.5 \%( \pm 1.5 \%$, with a statistical confidence Student test of 97.5\%). The two observed largest FWS values in 1994 and 1998 (Figure 7) correspond to the observed lowest snow cover extent (during the fall for 1994 and 1998; spring for 1998). These years also correspond to the highest yearly sum of positive degree-days during this period (sum of positive temperature [Fillol, 2003]). Moreover, 1998 corresponds to the exceptional El Niño warming episode [Atkinson et al., 2005].

[29] For northern Eurasia, we focus on the Ob basin (Figure 8), as most of the Eurasian territory is characterized by small FWS values and small interannual variations. Moreover, over Finland and Norway, mountains can bias our FWS calculation. Figure 8 shows an increase in wetland areas both during the spring and the summer. The spring FWS increase $(27 \% \pm 8 \%$, with a statistical confidence Student test of $90 \%$ ) can be related to a smaller sum of daily total snow cover extent (Figure 8, bottom) and to larger flooded areas during snow free periods. The observed summer FWS increase $(8.5 \% \pm 1.5 \%$, with a statistical confidence Student test of $97.5 \%$ ) is in agreement with the recent observed increase in mean annual discharge of freshwater from the largest Eurasian rivers to the Arctic Ocean [Peterson et al., 2002]. As a matter of fact, for watersheds with large floodplains like the $\mathrm{Ob}$ basin, the water discharge is functionally related to the water level (flooded area) [Ranz, 1982]. For each specific point on the river, a functional relation ("rating curve") exists between discharge and water level [Ranz, 1982]. Analysis of these two parameters for the Salekhard (the last observation point at the river outlet) has been done recently by Kouraev et al. [2004]. The comparison of in situ observed water level and discharge for different periods made by these authors shows that the relation between these two parameters is relatively constant over the last 30 years. They also established a relation between water level derived from TOPEX/Poseidon satellite altimetry and in situ measured discharge at Salekhard. Depending on the shape of the river bed and river valley, surface or flooded areas could also be linked to the water level and discharge. Discharge variations from ground-based measurements and from satellite altimetry for Salekhard [Kouraev et al., 2004] are in accordance with our observed FWS variations. For example, the high spring FWS values observed for 1995 and 1997 (Figure 8, top) correspond to marked spring water flow positive anomalies that occurred during these years, also linked to the observed lowest spring snow cover extent (Figure 8, bottom). The lowest spring FWS value for 1996 corresponds to the lowest water flow negative anomaly for the 1992-2002 period, and to the highest spring SCE (Figure 8, bottom). The observed lowest fall FWS values in 1998 correspond to the highest fall SCE. Moreover, the highest summer FWS value observed for 1999 (Figure 8, weeks 39 to 52) corresponds to the highest summer positive anomaly of water flow. In this particular type of watershed, the microwavederived FWS estimates and their dynamics (period of spring flood, dates of the beginning/end of the open water period) 
could provide valuable information for discharge estimates, snow dynamics and water budget variability.

[30] Similar investigations were performed over the MacKenzie River basin, in northwest Canada (not shown). In this case, no significant interannual variations are observed for the whole basin, except in particular sub-areas such as near Great Slave Lake $\left(62^{\circ} \mathrm{N}, 114^{\circ} \mathrm{W}\right)$ (Figure 3) where significant variations occurred in 1998: latest freezeup date and one of the earliest break up date over the period 1988 to 1998 [Rouse, 2000]. Note that the masks we applied over the large lakes with a surrounding 1-pixel margin (see Figure 3) hide a large part of the flooded area extent in the case of the MacKenzie basin.

\section{Conclusion}

[31] A new method for mapping the extent of inundated surfaces (small lakes, reservoirs, shallow waterbodies) and wetlands from satellite microwave emissivities allows us to update existing values of wetland extent variations during the year. As the seasonal behavior of northern wetland extent is strongly driven by the snow/freeze period, this has been carefully determined on a pixel-by-pixel basis. The results show a maximum wetland extent during JulyAugust-September leading to a significantly longer wetland active period, from 26 weeks at $48^{\circ} \mathrm{N}-50^{\circ} \mathrm{N}$ to 11 weeks at $66^{\circ} \mathrm{N}-68^{\circ} \mathrm{N}$, than previously published by Prigent et al. [2001], over Canada-Alaska.

[32] The low FWS values are very sensitive to the $\varepsilon_{d r y}$, and further work should focus special attention on this parameter. In Canada-Alaska, the observed increase, over the 1988-2001 period, in the sum of total FWS area is linked to a smaller total snow cover extent giving a longer snow free period. In the $\mathrm{Ob}$ basin, an increase in the total FWS area during spring and summer is related to a smaller total snow cover extent and to a larger water discharge in the $\mathrm{Ob}$ basin. The new database derived from the proposed method on a weekly basis can be useful for validating land surface-atmosphere transfer schemes over northern latitudes, and thus for studying the impact of climate change on wetland greenhouse gas emission.

[33] Acknowledgments. Research funding was provided by the Canadian Fund for Climate and Atmospheric Sciences, the Canadian Natural Sciences and Engineering Research Council, Environment Canada (CRYSYS project), the French Ministère de la Recherche (ACI Observation de la Terre, ACI Changement Climatique) and the Ministère des Affaires Étrangères (Coopération France-Québec). We thank E. Poutou, G. Krinner, N. Roulet and J. Cogley for helpful comments, and C. Prigent for providing her data and helpful discussions.

\section{References}

Armstrong, R., and M. Brodzik (2001), Recent Northern Hemisphere snow extent: A comparison of data derived from visible and microwave satellite sensors, Geophys. Res. Lett., 28(19), 3673-3676.

Armstrong, R., and M. Brodzik (2002), Northern Hemisphere EASE-Grid Weekly Snow Cover and Sea Ice Extent Version 2 [CD-ROM], Natl. Snow and Ice Data Cent., Boulder, Colo.

Armstrong, R., K. Knowles, M. Brodzik, and M. Hardman (2005), DMSP SSM/I Pathfinder Daily EASE-Grid Brightness Temperatures, August 1987 to December 2003 [CD-ROM], Natl. Snow and Ice Data Cent., Boulder, Colo.

Atkinson, D., et al. (2005), Canadian cryospheric response to an anomalous warm summer, Atmos. Ocean, in press.

Basist, A., N. Grody, T. Peterson, and C. Williams (1998), Using the Special Sensor Microwave/Imager to monitor land surface temperatures, wetness, and snow cover, J. Appl. Meteorol., 37, 888-911.
Brown, R. D. (2000), Northern Hemisphere snow cover variability and change, 1915-1997, J. Clim., 13, 2339-2355.

Cogley, J. (2003), GGHYDRO - Global Hydrographic Data, release 2.3, Trent Tech. Note 2003-1, Dep. of Geogr., Trent Univ., Peterborough, Ont., Canada.

DeNoblet-Ducoudré, N., E. Poutou, J. Chappellaz, M. Coe, and G. Krinner (2002), Indirect relationship between surface water budget and wetland extent, Geophys. Res. Lett., 29(4), 1046, doi:10.1029/2001GL013929.

Fernandes, R., G. Palvic, W. Chen, and R. Fraster (2001), Canada wide $1 \mathrm{~km}$ water fraction derived from national topographic data base maps, http://geogratis.cdgi.gc.ca/download/Waterfraction/, Nat. Resour. Canada, Ottawa.

Fillol, E. (2003), Analyse de la variabilité climatique des régions boréales et subarctiques du Canada par télédétection; Validation du modèle régional canadien du climat, thèse de doctorat, 183 pp., Univ. de Sherbrooke, Sherbrooke, Quebec, Canada.

Fily, M., A. Royer, K. Goïta, and C. Prigent (2003), A simple retrieval method for land surface temperature and fraction of water surface determination from satellite microwave brightness temperatures in sub-arctic areas, Remote Sens. Environ., 85, 328-338.

Griffis, T., W. Rouse, and J. Waddington (2000), Inter-annual variability in net ecosystem $\mathrm{CO}_{2}$ exchange at a subarctic fen, Global Biogeochem. Cycles, 14, 1109-1121.

Grody, N., and A. Basist (1996), Global identification of snowcover using SSM/I measurements, IEEE Trans. Geosci. Remote Sens., 34, 237-249.

Kouraev, A. V., E. Zakharova, O. Samain, N. Mognard, and A. Cazenave (2004), Ob river discharge from TOPEX/Poseidon satellite altimetry (1992-2002), Remote Sens. Environ., 93, 238-245.

Krinner, G. (2003), Impact of lakes and wetlands on boreal climate, J. Geophys. Res., 108(D16), 4520, doi:10.1029/2002JD002597.

Latifovic, R., Z.-L. Zhu, J. Cihlar, and C. Giri (2002), Land cover of North America 2000, technical report, Can. Cent. for Remote Sens., Nat. Resour. Can., Ottawa.

Matthews, E., and I. Fung (1987), Methane emission from natural wetlands: Global distribution, area, and environmental characteristics of sources, Global Biogeochem. Cycles, 1, 61-86.

Mialon, A., M. Fily, and A. Royer (2005), Seasonal snow cover extent variation from microwave remote sensing data: Comparison with existing datasets, paper presented at EARSeL Workshop on Remote Sensing of Land Ice and Snow, Eur. Assoc. of Remote Sens. Lab., Bern, Switzerland. Owe, M., A. V. de Griend, R. D. Jeu, J. D. Vires, E. Seyhan, and E. Engman (1999), Estimating soil moisture from satellite microwave observation: Past and ongoing projects, and relevance to GCIP, J. Geophys. Res., 104(D16), 19,735-19,742.

Peterson, B., et al. (2002), Increasing river discharge to the Arctic Ocean, Science, 298, 2171-2173.

Poutou, E., G. Krinner, C. Genthon, and N. de Noblet-Ducoudré (2004), Role of soil freezing in future boreal climate change, Clim. Dyn., 23, 621-639.

Prigent, C., W. Rossow, and E. Matthews (1998), Global maps of microwaves land surface emissivities: Potential for land surface characterization, Radio Sci., 33(3), 745-751.

Prigent, C., E. Matthews, F. Aires, and W. Rossow (2001), Remote sensing of global wetland dynamics with multiple satellite data sets, Geophys. Res. Lett., 28, 4631-4634.

Ranz, S. (1982), Measurements and computation of streamflow: Volume 2, Water Supply Pap. 2175, pp. 285-631, U.S. Geol. Surv., Washington, D. C.

Roulet, N., A. Jano, C. Kelly, L. Klinger, T. Moore, R. Protz, J. Ritter, and W. Rouse (1994), Role of the Hudson Bay lowland as a source of atmospheric methane, J. Geophys. Res., 99(D1), 1439-1454.

Rouse, W. (2000), Progress in hydrological research in the MacKenzie GEWEX study, Hydrol. Processes., 14, 1667-1685.

Walter, B., M. Heimann, and E. Matthews (2001), Modeling modern methane emissions from natural wetlands: 2 . Interannual variations 1982-1993, J. Geophys. Res., 106(D24), 34,207-34,219.

Wang, L., M. Sharp, R. Brown, C. Derksen, and B. Rivard (2005), Evaluation of spring snow covered area depletion in the Canadian Arctic from NOAA snow charts, Remote Sens. Environ., 95, 453-463.

Winter, T., and D. Rosenberry (1998), Hydrology of prairie pothole wetlands during drought and deluge: A 17 year study of the Cottonwood Lake wetland complex in North Dakota in the perspective of longer term measured and proxy hydrological records, Clim. Change, 40, 189-209.

M. Fily and A. Mialon, Laboratoire de Glaciologie et Géophysique de l'Environnement CNRS/UJF, 54, rue Molière, Domaine Universitaire, F-38402 St Martin d'Hères, France. (michel.fily@1gge.obs.ujf-grenoble.fr; mialon@lgge.obs.ujf-grenoble.fr)

A. Royer, Centre d'Applications et de Recherches en Télédétection, Université de Sherbrooke, Sherbrooke, (Québec), Canada, J1K2R1. (alain.royer@usherbrooke.ca) 
a)

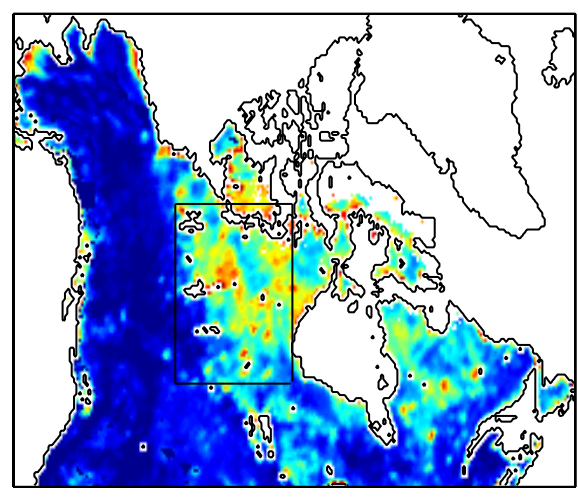

c)

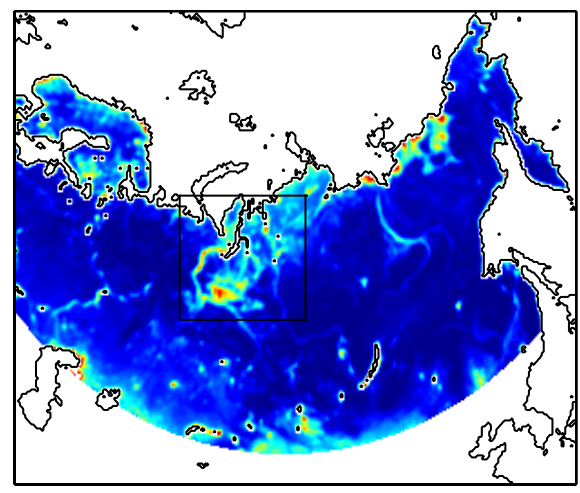

FWS

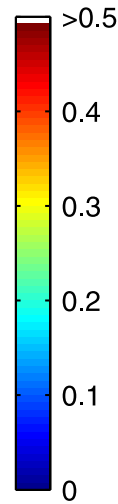

FWS

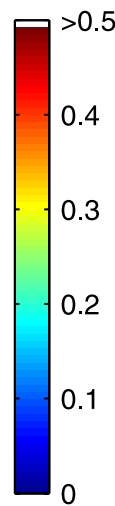

b) Great Slave Lake

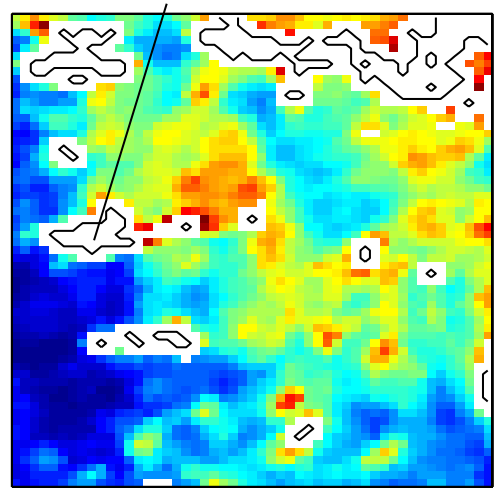

d)

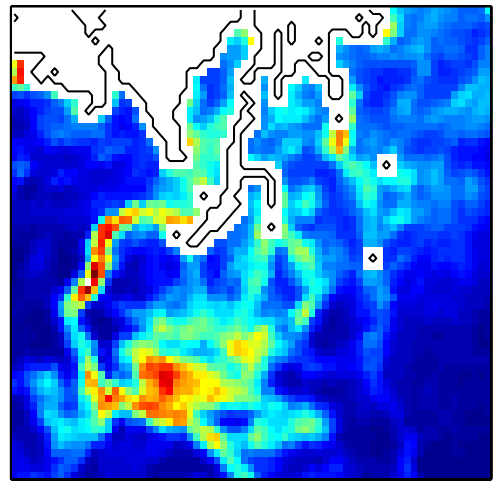

Figure 3. Fraction of water surface distribution giving the mean wetland and waterbody extent (a) over Canada-Alaska and (b) over the MacKenzie basin, for week 37, and (c) over northern Eurasia and (d) over the Ob basin for the week 27, averaged over the 1988-2001 period, at $37 \mathrm{GHz}$, vertical polarization and AM overpasses. Coastal zones, large lakes and Northern Islands are masked (white areas). 